
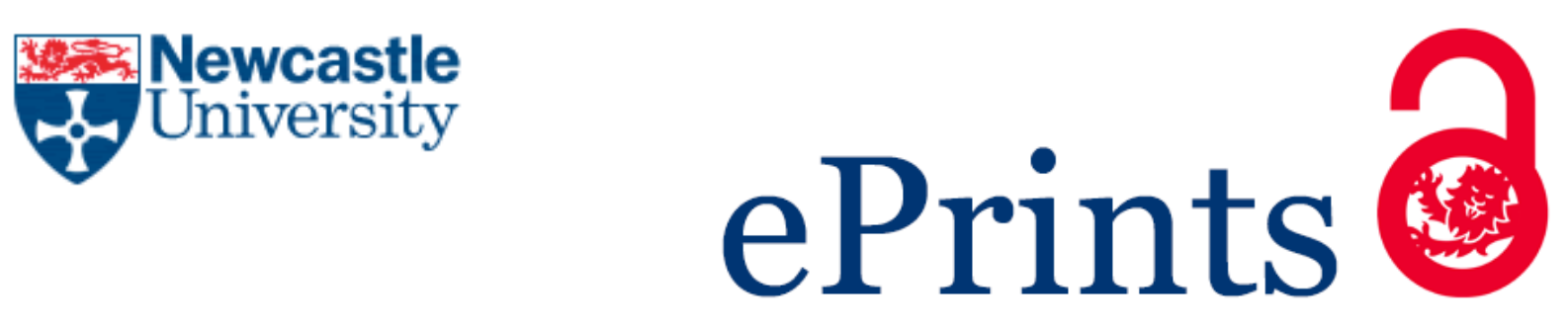

Pain R.

Ways beyond disciplinarity.

Children's Geographies 2010, 8(2), 223-225

\title{
Copyright:
}

This is an Accepted Manuscript of an article published by Taylor \& Francis in Children's Geographies on 21/4/2010, available online: https://doi.org/10.1080/14733281003691525

DOI link to article:

https://doi.org/10.1080/14733281003691525

Date deposited:

$20 / 12 / 2017$

Embargo release date:

21 April 2011

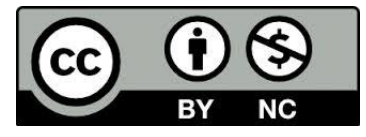

This work is licensed under a Creative Commons Attribution-NonCommercial 3.0 Unported License 


\section{Ways beyond disciplinarity}

Rachel Pain

Debates around interdisciplinarity, multidisciplinarity, postdisciplinarity and transdisciplinarity are longstanding. The lexicon changes, but the book remains mostly closed - at least from the perspective of growing numbers of researchers whose most significant connections are beyond the academic. As material and symbolic parts of our histories and contemporary practices, and ways of being as academics, disciplines are undoubtedly important. But this debate has a downside. It privileges disciplines as producers and containers of knowledge. It reinforces the feeling that academic knowledge is standalone, disconnected from everything else that's going on in the world. It might even distract from critiques about the status of academic knowledge as powerful, pitiful or just incomprehensible by those on the outside. A fuller geography ${ }^{1}$ of how disciplines develop must also include the waybeyond-disciplinary engagements that shape our work, whether or not we consciously look for or actively pursue them (Fuller and Askins forthcoming; mrs kinpaisby 2008). I hope the personal account that follows doesn't seem too paradoxically introverted. I weave it in to show that the wider worlds I work and live in have led me as an academic, rather than me forging any innovative (inter)disciplinary path.

Geography always appealed as 'an interstitial subject and an impulse to interdisciplinarity' (Smith forthcoming), and occupying in-between disciplinary positions has helped me to think about and research with children and young people. During my PhD I was located as firmly in criminology and feminist sociology as geography, integrating ideas and methodologies about crime, fear and gender. An interest in old age was excited by social gerontologists' poststructuralist framings of 
what constitutes the subject, and Sarah Harper and Glenda Laws' (1995) sophisticated, feminist-inspired geographical take. I moved into children's/youth geographies from this field, recognising young people's pivotal and complex position in relation to older people's emotional landscapes. My research with young people about crime and their own fears drew on critical criminology and the sociology as well as geography of youth. Intergenerationality emerged from this relational perspective, and social work and youth studies were now among the disciplines that inspired me.

This classic, convoluted interdisciplinary route - describing an individual journey but also the wider swamp of ideas we are busy swimming around in (when we look up, we see that we're not nearly as innovative as we were thinking...) - is only part of the story. There are at least three additional sets of connections that shape how knowledge develops.

The first is intergroup relations - how these make themselves known to researchers bent on studying people in separate boxes (Hopkins and Pain 2007; Vanderbeck 2007). It was older people as research respondents who prompted, firstly, my recognition of their resilience as well as fearfulness, and secondly that old age and childhood are constituted in relation to each other (Pain 2001).

The second is how practitioner and policy communities interplay with the development of academic understandings in a two-way flow of knowledge (Burgess 2005). My interest in intergenerational geographies was really sparked in 1996 when I was a voluntary consultant with LifeLink, an innovative local project using intergenerational practice to tackle the fear of crime. Seeing and being part of this practice altered my disciplinary perspective, as did later involvement with networks of intergenerational practitioners and policy-makers (Pain 2005).

The third is children's and young people's own knowledges, framings of the world, and research. Participatory research has meant very different things: often wrongly 
framed as a methodological shift, it does nonetheless entail exciting, visual, emotionally powerful methods with children and young people that are themselves batted rapidly between disciplines and from and to practitioner worlds outside. Sometimes this seems to constitute little but methodsism in children's geographies: experimentalism without a clear sense of political purpose.

However, in its original and most profound sense, participatory research is a not a methodological shift but an epistemological and ontological one, about who asks and answers research questions (Cahill et al 2008; Fine et al 2007). This is a different take on postdisciplinarity as 'follow[ing] arguments and processes to where they lead, rather than stopping at conventional disciplinary boundaries' (Sayer 1999); this goes way beyond disciplines. It involves a timid disciplinarianism: stepping back, decentring ourselves as knowledge producers, listening a bit more, telling a bit less, opening up to the many other sites of knowledge production. When people who are traditionally cast as research subjects (re)define the starting point of research and tell their own lives for their own purposes, persistent categories and assumptions about 'childhood' and 'adulthood' are more likely to be queried and queered (Kesby 2007). Moreover, while debates about disciplinarity often seem founded on a basic assumption that 'the discipline' is the site of philosophical orientation/theory/methodological approach, with 'the field' merely the site of practice/engagement/empirics, over the years participatory work in children's and youth geographies has muddied these binaries. And so the relations between theory/practice, and disciplinary/way-beyond-disciplinarity have collided and been blurred in ways that are productive, both intellectually and politically.

In my own work, this process has been a challenging, frustrating, partial, joyful and invigorating effort: co-researching with young people and community activists, trying to follow their priorities for what research and methods are about, their conceptualisation of findings, their ideas for dissemination. There are significant dangers, not just of romanticism and dogmatism, but of proselytising a process that 
holds the continued possibility of academics mining and colonising other knowledge sites.

But these kinds of collaborations can force us to ask deeper, searching and useful questions, and yield richer, more innovative, more equitable and useful outcomes. Beyond methodsism, the reorientation that has begun in some parts of children's and youth geographies is perhaps one of the healthiest ways to think about what postdisciplinarity means.

\section{Notes}

${ }^{1}$ This commentary is dedicated to the memory of Duncan Fuller, who inspired me and many others on what fuller (more rounded, connected, engaged, public and participatory) geographies could entail, as Sophie Wynne-Jones and Kelvin Mason's session on 'Fuller geographies' at the 2009 IBG/RGS conference demonstrated. I am also grateful to Caitlin Cahill for her comments on this piece.

\section{References}

Burgess, J. 2005. Follow the argument where it leads: some personal reflections on 'policy-relevant' research Transactions of the Institute of British Geographers, 30 (3), 273-281.

Cahill, C., Rios-Moore, I. and Threatts, T. 2008. Different eyes / open eyes: community-based Participatory Action Research. In J. Cammarota and M. Fine, eds. Revolutionizing Education: Youth Participatory Action Research in Motion. London, Routledge, 89-124. 
Fine, M., Tuck, J.E. and Zeller-Berkman, S. 2007 Do you believe in Geneva? In N.

Denzin, L.T. Smith and Y. Lincoln, eds. Handbook of Critical and Indigenous Knowledges. Beverley Hills: Sage Publications.

Fuller, D. and Askins, K. forthcoming. Public geographies II - being organic. Progress in Human Geography.

Harper, S. and Laws, G. 1995. Rethinking the geography of ageing. Progress in Human Geography, 19 (2), 199-221.

Hopkins, P. and Pain, R. 2007. Geographies of age: thinking relationally. Area 39 (3), 287-294.

Kesby, M. 2007. Methodological insights on and from Children's Geographies.

Children's Geographies, 5 (3), 193-205.

mrs kinpaisby 2008. Taking stock of participatory geographies: envisioning the communiversity. Transactions of the Institute of British Geographers, 33 (3), 292-299.

Pain, R. 2005. Intergenerational relations and practice in the development of sustainable communities. Report to Office of the Deputy Prime Minister, London.

Sayer, A. 1999. Long live postdisciplinary studies! Sociology and the curse of disciplinary parochialism/imperialism. Paper presented to the British Sociological Association, Glasgow UK. Available at http://www.lancs.ac.uk/fass/sociology/papers/sayer-long-live-postdisciplinarystudies.pdf (accessed 21 September 2009).

Smith, S. J. forthcoming. Geography: looking forward. Transactions of the Institute of British Geographers

Vanderbeck, R. 2007. Intergenerational geographies: age relations, segregation and reengagements. Geography Compass, 1, 200-21. 